\title{
AGE-RELATED VARIATION IN WING SHAPE DIFFERS BETWEEN BIRD ORDERS: IMPLICATIONS FOR INTERPRETATION OF THE POINTEDNESS INDEX (C2 AXIS) IN A SIZE-CONSTRAINED PRINCIPAL COMPONENT ANALYSIS (SCCA)
}

\author{
LA VARIACIÓN DE LA FORMA DEL ALA ASOCIADA CON LA EDAD \\ DIFIERE ENTRE ÓRDENES DE AVES: IMPLICACIONES PARA \\ LA INTERPRETACIÓN DEL ÍNDICE DE APUNTAMIENTO (EJE C2) \\ EN UN 'SIZE CONSTRAINED COMPONENTS ANALYSIS' (SCCA)
}

\author{
Xabier CABodevilla ${ }^{1,2,4}$ * , Javier PéRez-Tris ${ }^{3}$, Lara Moreno-Zarate ${ }^{2}$, \\ Antón Pérez-Rodríguez ${ }^{3}$, José Francisco Lima-Barbero ${ }^{2,5}$, \\ María Cruz CAMACHO ${ }^{2}$, Diego VillanuA ${ }^{4}$, Rubén IBÁÑEZ ${ }^{4}$, \\ Andrea Gerboles ${ }^{4}$ and Beatriz ArRoyo ${ }^{2}$
}

\begin{abstract}
SUMMARY.- There is a strong relationship between bird wing morphology and flight style. Wing shapes are related to manoeuvrability, flight speed, energetic costs during flight and take-off speed. Wing shape differences among species have been frequently studied but differences can also be found within species, between sexes and age groups. Many studies have assessed differences in wing shape between juveniles and adults in different passerine species but little is known about such differences in other bird orders. Performing a Size Constrained Components Analysis (SCCA) and a graphical approximation, we analysed the wing shape of juveniles and adults of eight species, including four passerines and four non-passerines of three different orders. According to a graphical approximation, we observed that wing shape differences between age groups differ among species. In the non-passerine species considered, juveniles have more pointed and concave wings than adults. In contrast, in the four passerine species, juveniles have more rounded wings than adults. However, the results for the C2 axis of SCCA
\end{abstract}

1 Department of Zoology and Animal Cell Biology, Faculty of Pharmacy, University of the Basque Country (UPV/EHU), Paseo de la Universidad 7, 01006 Vitoria-Gasteiz, Alava, Spain.

2 Instituto de Investigación en Recursos Cinegéticos (IREC) (CSIC-UCLM-JCCM), Ronda de Toledo 12, 13005 Ciudad Real, Spain.

3 Department of Biodiversity, Ecology and Evolution, Faculty of Biology, Universidad Complutense de Madrid (UCM), Madrid, Spain.

4 Department of Ornithology, Aranzadi Sciences Society, Zorroagagaina 11, 20014 Donostia, Spain.

5 Sabiotec Spinoff, Ed. Polivalente UCLM, Camino de Moledores, 13005 Ciudad Real, Spain.

* Corresponding author: xabier.cabodevilla@ehu.eus 
(index of pointedness) do not completely agree with the graphical approximation. Our results showed that the $\mathrm{C} 2$ axis does not represent the same vector of wing shape variation in all species. The contribution of changes in $\mathrm{C} 2$ to variation in wing pointedness seemed to depend on the position of the wing tip, which is a good index of pointedness only when the wing tip is in the two most distal primary feathers. Surprisingly, the adults of some species do not have longer wings than the corresponding juveniles, because the feathers that define the wing tip do not grow longer during the first complete moult. We discuss the role of the first complete moult in changing the shape of juvenile wings into adult wings, and the implications of our results for the analysis of bird wing shape. - Cabodevilla, X., PérezTris, J., Moreno-Zarate, L., Pérez-Rodríguez, A., Lima-Barbero, J.F., Cruz Camacho, M., Villanua, D., Ibáñez, R., Gerboles, A. \& Arroyo, B. (2020). Age-related variation in wing shape differs between bird orders: implications for interpretation of the pointedness index ( $\mathrm{C} 2$ axis) in a size-constrained principal component analysis (SCCA). Ardeola, 67: 341-354.

Key words: manoeuvrability, moult, predator escape, selection forces, take off, wing morphology.

RESUMEN.-Existe una fuerte relación entre la morfología alar y el estilo de vuelo de un ave. La forma del ala está relacionada con la maniobrabilidad, la velocidad de vuelo, los costes energéticos durante el vuelo o la velocidad de despegue. Las diferencias en la forma del ala entre especies han sido estudiadas con frecuencia, pero también existen diferencias dentro de una especie, entre sexos y grupos de edad. Muchos estudios han evaluado las diferencias en la forma alar entre juveniles y adultos en diferentes especies de paseriformes, pero se sabe poco acerca de las diferencias en la forma alar entre grupos de edad en otros órdenes de aves. Realizando un análisis SCCA ('Size Constrained Components Analysis') y una aproximación gráfica, analizamos la forma alar de juveniles y adultos de ocho especies, cuatro paseriformes y cuatro no paseriformes de tres órdenes diferentes. De acuerdo con la aproximación gráfica, observamos que las diferencias en la forma alar entre grupos de edad difieren entre especies. En las especies de no paseriformes estudiadas, los juveniles tienen alas más puntiagudas y cóncavas que los adultos. En contraste, en las cuatro especies de paseriformes, los juveniles tienen alas más redondeadas que los adultos. Sin embargo, los resultados del eje C2 del SCCA no concuerdan completamente con la aproximación gráfica. Nuestros resultados mostraron que el eje C2 no representa el mismo vector de variación de la forma del ala en todas las especies. La contribución de los cambios en C2 a la variación del apuntamiento del ala parece depender de la posición de la punta del ala, siendo un buen índice de apuntamiento solo cuando la punta del ala está en las dos plumas primarias más distales. Sorprendentemente, los adultos de algunas especies no tienen alas más largas que los respectivos juveniles, debido a que la pluma que define la punta del ala no tiene un incremento de tamaño durante la primera muda completa. Describimos cómo la primera muda completa es clave en el cambio de la morfología alar entre el ala de los juveniles y el ala de los adultos, y discutimos las implicaciones de nuestros resultados en relación con el análisis de la forma de las alas de las aves. -Cabodevilla, X., Pérez-Tris, J., Moreno-Zarate, L., Pérez-Rodríguez, A., Lima-Barbero, J.F., Cruz Camacho, M., Villanua, D., Ibáñez, R., Gerboles, A. y Arroyo, B. (2020). La variación de la forma del ala asociada con la edad difiere entre órdenes de aves: implicaciones para la interpretación del índice de apuntamiento (eje C2) en un 'Size Constrained Components Analysis' (SCCA). Ardeola, 67: 341-354.

Palabras clave: despegue, escape de predador, fuerzas de selección, maniobrabilidad, morfología alar, muda.

\section{INTRODUCTION}

Flight is one of the most important characteristics of birds. Just as there are different strategies and ways of moving over land
(Biewener \& Patek, 2018), there are also many forms of flying (Hickman et al., 2008; Biewener \& Patek, 2018). There are birds that can fly at high speeds, birds with incredible manoeuvrability, birds with powerful 
take-offs, soaring birds or birds with energetically efficient flight (Savile, 1957; Hickman et al., 2008; Biewener \& Patek, 2018). The most important variable that makes this heterogeneity possible is wing shape (Hickman et al., 2008). Wing morphology is directly linked to bird activity and behaviour (del Hoyo et al., 1997; Lockwood et al., 1998; Swaddle \& Lockwood, 1998; Burns \& Ydenberg, 2002; Swaddle \& Lockwood, 2003) and thus provides information about the relative importance of different activities and behaviours in the life of birds (PérezTris \& Tellería, 2001; Nadal et al., 2017; Cabodevilla et al., 2018).

During the last few decades, many studies have focussed on the study of bird wing morphology (Alatalo et al., 1984; Winkler \& Leisler, 1992; Lockwood et al., 1998; PérezTris \& Tellería, 2001; Milá et al., 2008; Arizaga \& Barba, 2011). These studies have found that species with longer migration distances have more pointed wings (Senar et al., 1994; Norberg, 1995; Lockwood et al., 1998; Bowlin \& Wikelski, 2008; Minias et al., 2015; Vágási et al., 2016; Watanabe, 2016), with few exceptions, e.g. Barn Swallow Hirundo rustica (Huber et al., 2016). Pointed wings allow more energetically efficient long flights (Bowlin \& Wikelski, 2008) but decrease take-off power (McFarlane et al., 2016) and reduce manoeuvrability (Hickman et al., 2008). For this reason, sedentary birds have more rounded wings, which benefit them in their daily activity, allowing more manoeuvrability, more powerful take-offs and greater ability to escape from predators (del Hoyo et al., 1997; Swaddle \& Lockwood, 1998; Swaddle \& Lockwood, 2003; McFarlane et al., 2016). These are, indeed, two ends of the spectrum of variation in wing shape design: high aspect ratio wings (pointed and concave), typical of long-distance migrants and elliptical wings (rounded and convex), typical of sedentary, terrestrial and forest birds.
Differences in wing shape may occur not only between different species or populations of the same species with contrasting migratory regimes (Pérez-Tris \& Tellería, 2001), but also between ages and sexes of the same species and populations (Alatalo et al., 1984; Fernández \& Lank, 2007; Green et al., 2009; Nadal et al., 2017). For instance, juvenile passerines usually have more rounded wings than adults (Alatalo et al., 1984; Milá et al., 2008, Green et al., 2009, de la Hera et al., 2014), which aids first flights, improving survival chances early in life (Alatalo et al., 1984; de la Hera et al., 2014). Although the order Passeriformes includes more than $50 \%$ of living bird species (Gill \& Donsker, 2019), it is only one among the 40 extant orders of the class Aves (Gill \& Donsker, 2019). Among the few studies that have assessed variation between age classes in wing shape in nonpasserine birds, one carried out on Western Sandpipers Calidris mauri (Charadriiformes), a migratory species, found the same pattern as in passerines, with juveniles having more rounded wings than adults (Fernández \& Lank, 2007). In turn, two other studies, of Red-Legged Partridges Alectoris rufa (Galliformes, sedentary) and European Turtle Doves Streptopelia turtur (Columbiformes, migratory) found the opposite pattern (Nadal et al., 2017; Cabodevilla et al., 2018). This illustrates that the pattern of wing shape differences between juvenile and adult passerines cannot be generalised to all species and bird orders. The only pattern that seems to hold true across bird species and orders is that adults have longer wings than juveniles (Figuerola \& Gutiérrez, 2000; Nowakowski, 2002; Green et al., 2009; Furness \& Furness, 2016; Cabodevilla et al., 2018).

Here, we assessed differences in wing shape between juveniles and adults of four migratory species from the previously studied non-passerine orders (Charadriiformes, Galliformes and Columbiformes), and compared them with four species of the order Passeri- 
formes (three migratory and one sedentary). We analysed how the first primary moult affects wing shape in these species, aiming to reveal general patterns of ontogenetic variation in wing shape.

\section{MATERIAL AND METHODS}

\section{Feather and bird measurements and wing-shape data}

Our study species included birds from four different orders: Eurasian Woodcock Scolopax rusticola (Charadriiformes); Common Woodpigeon Columba palumbus and European Turtle Dove Streptopelia turtur (Columbiformes); Common Quail Coturnix coturnix (Galliformes); and, from the order Passeriformes, Eurasian Magpie Pica pica, Song Thrush Turdus philomelos, Eurasian Blackbird Turdus merula and European Robin Erithacus rubecula, these include both migratory and non-migratory species of a wide size range (Table 1).

Measurements of the birds were taken in different Spanish provinces, in different seasons and years (Table 1; Supplementary Material, Appendix 1, Figures A1 and A2). Birds were aged as juveniles: in their first calendar year, or adults: having undergone their first complete moult, using plumage criteria, following Svensson (1992) and Demongin (2013). Sex was not considered because it could not be determined in most species. In addition, it should be mentioned that due to the trapping method used in the case of Common Quail, only males were captured.

In all birds, we measured wing length and the lengths of each of the nine outermost primaries (except in Woodpigeons, in which we only measured the five outermost primaries because many birds had already moulted the five innermost ones). Feather length was measured from their insertion point into the skin to the feather tip. Three species (Woodcock, Turtle Dove and Woodpigeon) have 11 primaries, but the outermost (P11) is very reduced and was not considered. Here primaries are numbered ascendantly, i.e. P1 is the innermost. Most measurements were taken by the same sampler (X.C.); however, in the cases of Quail and Song Thrush there were several samplers (Table 1).

To assess wing shape, we carried out a Size Constrained Components Analysis (SCCA), developed by Lockwood et al. (1998), for each species, using the SAS 9.1 statistical package (SAS Institute 2002). The SCCA is derived from a Principal Components analysis (PCA) using the measurements of the eight outermost long primaries (the vestigial distal primary of passerines, P10, is not considered). It incorporates a rigorous geometric size model, such that all the isometric effects are picked up in the first axis, and the rest of the components explain specific differences in wing shape. In particular, the second axis (hereafter C2) is usually interpreted as a measure of pointedness (Lockwood et al., 1998). In our case, the length of the outermost primaries showed positive loading while those of inner primaries showed negative loading in C2 (Table 2; Supplementary Material, Appendix 2, Table B1), meaning that birds scoring high $\mathrm{C} 2$ values had more pointed wings (Lockwood et al., 1998).

As an index of body size, we measured forearm length in hunted birds and tarsus length in birds captured during ringing sessions. In species for which we did not have forearm measurements (Quail, Woodpigeon and Song Thrush), we used an index related to the non-feathered (NF) part of the wing, calculated as wing length minus the length of the longest feather. We did not use tarsus length because this variable was not available in all studied individuals. However, we compared NF with tarsus length and forearm length in Magpies and Blackbirds, for which we had sufficient data for each variable (69 measurements of NF and forearm length and 59 of tarsus length for Magpies, 36 measurements of forearm and 37 measures of NF 


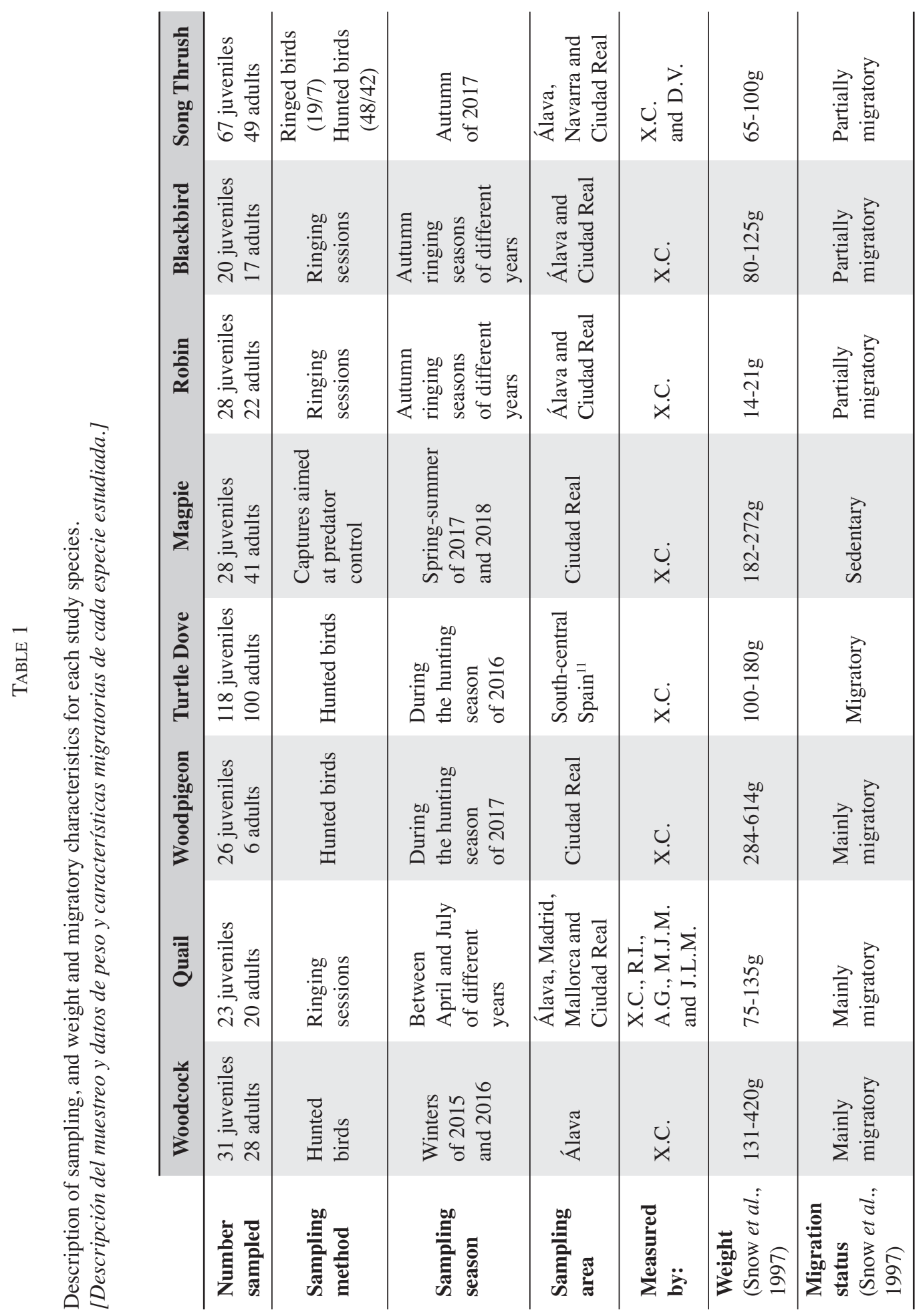


TABLE 2

Structure of the C2 component of the SCCA conducted for each species. The complete SCCA results are shown in Table $\mathrm{S} 1 . \%$ of shape variance explained $=\%$ of variance explained after removing the variance explained by $\mathrm{C} 1$.

[Estructura del componente C2 del SCCA realizado para cada especie. El resultado completo de SCCA se muestra en la Tabla S1. "\% of shape variance explained" = \% de la varianza explicada tras eliminar la varianza explicada por el C1.]

\begin{tabular}{|c|c|c|c|c|c|c|c|c|}
\hline & $\begin{array}{l}\text { Woodcock } \\
\text { (C2) }\end{array}$ & $\begin{array}{l}\text { Quail } \\
\text { (C2) }\end{array}$ & $\begin{array}{l}\text { Woodpigeon } \\
\text { (C2) }\end{array}$ & $\begin{array}{l}\text { Turtle Dove } \\
\text { (C2) }\end{array}$ & $\begin{array}{l}\text { Magpie } \\
\text { (C2) }\end{array}$ & $\begin{array}{l}\text { Robin } \\
\text { (C2) }\end{array}$ & $\begin{array}{l}\text { Blackbird } \\
\text { (C2) }\end{array}$ & $\begin{array}{l}\text { Song Thrush } \\
\text { (C2) }\end{array}$ \\
\hline P10 & 0.527 & 0.432 & 0.699 & 0.633 & & & & \\
\hline P9 & 0.399 & 0.363 & 0.134 & 0.407 & 0.814 & 0.542 & 0.520 & 0.496 \\
\hline P8 & 0.237 & 0.404 & -0.141 & 0.158 & 0.218 & 0.304 & 0.391 & 0.240 \\
\hline P7 & 0.055 & -0.067 & -0.436 & -0.221 & 0.096 & 0.391 & 0.311 & 0.343 \\
\hline P6 & -0.182 & -0.300 & -0.533 & -0.293 & -0.023 & 0.023 & 0.155 & 0.189 \\
\hline P5 & -0.316 & -0.341 & & -0.327 & -0.159 & -0.176 & -0.157 & -0.139 \\
\hline P4 & -0.376 & -0.358 & & -0.311 & -0.26 & -0.320 & -0.380 & -0.358 \\
\hline P3 & -0.48 & -0.424 & & -0.265 & -0.278 & -0.452 & -0.389 & -0.439 \\
\hline P2 & & & & & -0.332 & -0.35 & -0.367 & -0.450 \\
\hline $\begin{array}{l}\% \text { shape } \\
\text { variance } \\
\text { explained }\end{array}$ & $\mathbf{5 7 . 5 5}$ & 51.43 & 88.26 & 63.67 & 60.07 & 36.29 & 58.27 & 48.76 \\
\hline
\end{tabular}

and tarsus length for Blackbirds). We found strong positive relationships between NF and forearm length $\left(\mathrm{F}_{1,35}=14.075, \mathrm{P}<0.001\right.$, for Blackbird and $\mathrm{F}_{1,68}=37.87, \mathrm{P}<0.001$, for Magpie) and between NF and tarsus length $\left(\mathrm{F}_{1,36}=6.49, \mathrm{P}<0.05\right.$, for Blackbird and $\mathrm{F}_{1,58}=21.32, \mathrm{P}<0.001$ for Magpie), supporting the use of NF as a reliable estimate of body size in the absence of forearm or tarsus length measurements.

\section{Statistical analyses}

We built General Linear Models (GLM), using the R package MASS (Venables et al., 2002), for each species to test whether wing shape (C2) varied among age groups, using the body size estimate (forearm or NF) as an additional covariate. We also included sampler identity as an explanatory variable in the case of Quail, and the state (dead or alive) in the case of Song Thrush, since measurements in dead and living individuals can differ significantly (Indykiewicz et al., 2019). We did not include sampler identity in the GLM of Song Thrush because one sampler measured the dead birds and the other the living birds, so the two variables covaried. As expected, and since the SCCA restricts body size effect to $\mathrm{C} 1$, the effect of the body size covariate was not significant in almost all species, with the exception of Turtle Dove $\left(\mathrm{F}_{1,215}=12.58\right.$, $\mathrm{P}<0.001)$. Therefore, except in this species, we discarded the body size covariate from the analyses. 
We also used GLMs to test whether the length of each individual primary varied among age groups, primary feather number and their interaction, including body size estimate as an additional covariate. As in the previous analysis, we included as additional variables sampler identity in the case of Quail and the state (dead or alive) in the case of Song Thrush. When the interaction between primary feather and age was significant, we performed a Tukey post-hoc analysis, using the R lsmeans package (Russell, 2016), to check which differences were significant for each primary feather. We also used the lsmeans package to calculate Least Square means for each age group and primary feather, adjusted by body size.

Finally, we performed another GLM to test for variation in wing length between adults and juveniles, including body size as a covariate. We included as additional explanatory variables sampler identity in the case of Quail and state (dead or alive) in the case of Song Thrush. In all models, we checked residuals of the model for validation. We used the ggplot 2 package of $\mathrm{R}$ (Wickham, 2016) to draw all the figures. All analyses, except the SCCA, were done in R 3.5.3 (R Core Team, 2019).

\section{RESULTS}

In seven of the eight studied bird species, adults had lower $\mathrm{C} 2$ values (i.e. more rounded wings) than juveniles (Figure 1), but significant differences only appeared in three nonpasserines (Woodcock: $\mathrm{F}_{1,57}=22.76, \mathrm{P}<$ 0.001; Woodpigeon: $\mathrm{F}_{1,30}=23.91, \mathrm{P}<0.001$; Turtle Dove: $\left.\mathrm{F}_{1,215}=105.82, \mathrm{P}<0.001\right)$ and Magpie $\left(\mathrm{F}_{1,67}=11.94, \mathrm{P}<0.001\right)$. They were marginally significant in Quail $\left(\mathrm{F}_{1,37}=3.79\right.$, $\mathrm{P}=0.06)$ and Robin $\left(\mathrm{F}_{1,48}=3.03, \mathrm{P}=0.09\right)$ and not significant in the other two species (Blackbird: $\mathrm{F}_{1,35}=1.74, \mathrm{P}=0.20$; Song Thrush $\left.\mathrm{F}_{1,112}=0.21, \mathrm{P}=0.64\right)$.
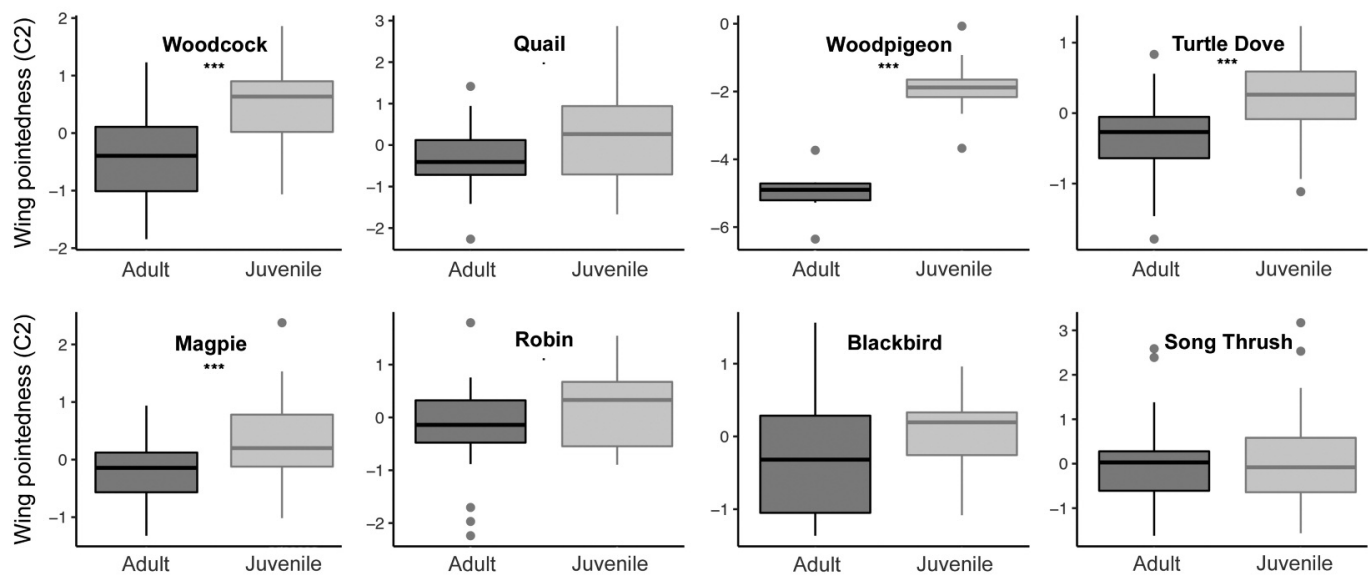

FIG. 1.-Boxplots of the second SCCA component in relation to age (adults in black, juveniles in grey) for each study species. Horizontal lines represent medians, boxes represent interquartile range and range bars the minimum and maximum values; $\cdot(\mathrm{P}<0.1) ;{ }^{*}(\mathrm{P}<0.05) ;{ }^{* *}(\mathrm{P}<0.01) ;{ }^{* * *}(\mathrm{P}<0.001)$. [Boxplots del segundo componente de SCCA en relación con la edad (adultos en negro, juveniles en gris) para cada una de las especies estudiadas. Las líneas oscuras representan la mediana, la caja representa el rango intercuartil y los bigotes los valores mínimo y máximo; $\cdot(P<0,1)$; ${ }^{*}(P<0,05)$; ** $(P<0,01)$; *** $(P<0,001)$.] 
In all studied species, during the first complete moult most primary feathers grew longer, except for P10 in all Passerines and P9 in Magpies (Figure 2). However, this size increase was not equal for all primaries: in all species, with the exception of Quail, in our GLM models the interaction between primary feather and age was significant or marginally significant. (Woodcock: $\mathrm{F}_{7,415}=$ 1.96, $\mathrm{P}=0.06$; Quail: $\mathrm{F}_{7,323}=1.0, \mathrm{P}=0.43$; Woodpigeon: $\mathrm{F}_{4,149}=11.53, \mathrm{P}<0.001$; Turtle Dove: $\mathrm{F}_{7,1727}=15.34, \mathrm{P}<0.001$; Magpie:
$\mathrm{F}_{8,602}=2.32, \mathrm{P}<0.05$; Robin: $\mathrm{F}_{8,413}=2.52$, $\mathrm{P}<0.05$; Blackbird: $\mathrm{F}_{8,305}=4.54, \mathrm{P}<0.001$; Song Thrush: $\mathrm{F}_{8,997}=3.65, \mathrm{P}<0.001$ ) (Supplementary Material Appendix 2, Table B2; Table B3).

In addition, differences were found among species in relation to feather elongation patterns. In the non-passerines, the primary feathers that most increased in length after the first complete moult were P7 to P4, depending on the species, while the distal primaries showed the least elongation (Figure

\section{a)}

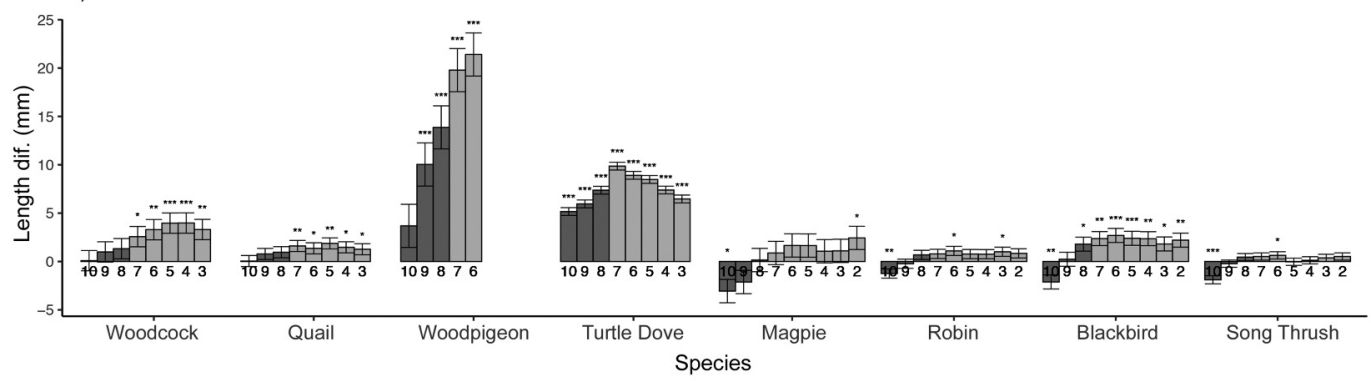

b)

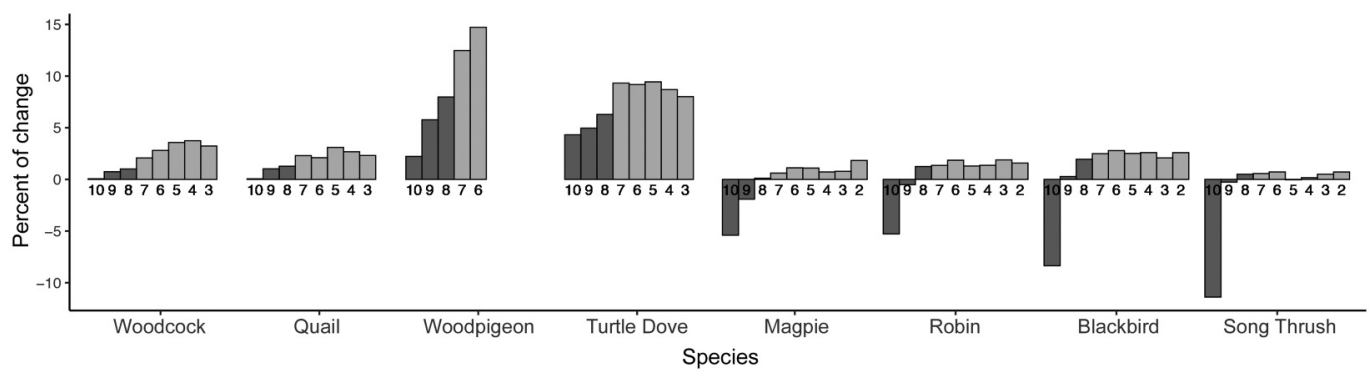

FIG. 2. - Length increase in primary feathers during the first complete moult, standardised for bird size (forearm in Woodcock, Turtle Dove, Magpie, Robin and Blackbird and non-feathered part of wing (NF) in Woodpigeon; body size had a non-significant effect in Quail and Song Thrush and was excluded). a) Actual change ( $\mathrm{mm} \pm \mathrm{SE}$ ) and significance of the post hoc analysis $\left({ }^{*} \mathrm{P}<0.05 ;{ }^{* *} \mathrm{P}<0.01\right.$; $\left.{ }^{* * *} \mathrm{P}<0.001\right)$. b) Percentage increase relative to juvenile feather length. The dark grey colour represents the most distal primary feathers (i.e., those in outer location relative to the body).

[Incremento de la longitud de las plumas primarias durante la primera muda completa, estandarizado para el tamaño de las aves (antebrazo en becada, tórtola europea, urraca, petirrojo y mirlo, y NF en paloma torcaz; el tamaño del cuerpo no tuvo un efecto significativo en la codorniz común y el zorzal común y se excluyó). a) Cambio real ( $\mathrm{mm} \pm \mathrm{SE}$ ) y nivel de significación del análisis post hoc $\left({ }^{*} \mathrm{P}<0,05\right.$; $\left.{ }^{* *} P<0,01 ;{ }^{* *} P<0,001\right)$. b) Incremento porcentual con respecto a la longitud de las plumas de los juveniles. El color gris oscuro representa las plumas primarias más distales (es decir, las que se encuentran mas alejadas del cuerpo).] 
$2)$. On the other hand, in the passerines, the most striking differences were the shorter distant primaries (P10) in adults compared to juveniles (Figure 2).

A graphical approximation showed that in the passerine species adults tended to show a more pointed and concave wing than juveniles (although in Song Thrush differences were minimal), in contrast to differences in $\mathrm{C} 2$ values, whereas in the four non-passerine species adults showed a more rounded and convex wing than juveniles, in accordance with differences in $\mathrm{C} 2$ values (Figure 3 ).

Finally, we did not find a significant increase in wing length after the first complete moult in four of the eight studied species, despite the increase in length in individual feathers. Only the adults of Woodpigeon, Turtle Dove, Robin and Blackbird showed significantly longer wings than juveniles (Woodpigeon: $\mathrm{F}_{1,31}=28.07, \mathrm{P}<0.001$; Turtle Dove: $\mathrm{F}_{1,217}=150.83, \mathrm{P}<0.001$; Robin: $\mathrm{F}_{1,47}=9.51, \mathrm{P}<0.01$; Blackbird: $\mathrm{F}_{1,35}=17.56$, $\mathrm{P}<0.001$ ) (Figure 4).

\section{DISCUSSION}

We found that in all study species, juveniles before their first primary moult had higher C2 values than adults (although differences were not always significant). This suggests that if we consider $\mathrm{C} 2$ as an index of wing pointedness, juveniles have more pointed wings than adults. However, C2 did not represent the same vector of variation in wing shape in all species, as revealed by the graphical approximation of wing shape (Figure 3). Higher C2 values were associated with longer distal primary feathers and shorter proximal feathers in all species. We therefore interpreted $\mathrm{C} 2$ as a measure of wing pointedness according to Lockwood et al. (1998). However, the contribution of changes in C2 to variation in wing pointedness seemed to depend on the position of the wing tip. In pointed wings, with the wing tip on (or close to) the most distal primary feather, an increase of $\mathrm{C} 2$ represents a clear increase in wing pointedness. This was the case for our
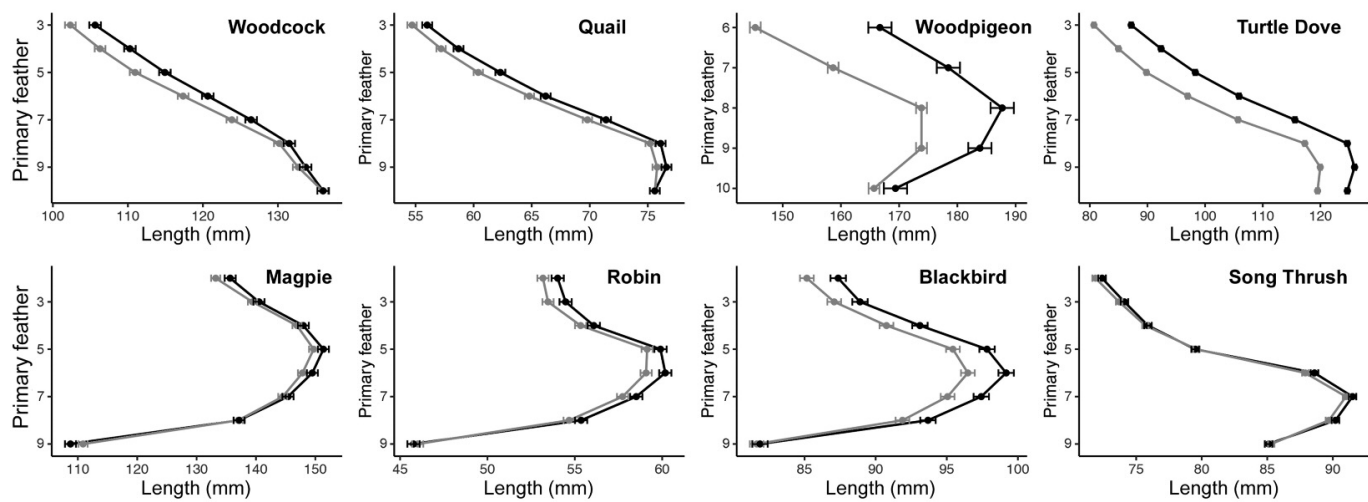

FIG. 3.-Graphical representation of the differences in wing shape between juvenile and adult birds: least square means $( \pm \mathrm{SE}$ ) of the length of primary feathers for adults (black) and juveniles (grey), controlling for body size (forearm or non-feathered part of wing (NF) length). In passerines, vestigial feather (P10) was not considered.

[Representación gráfica de las diferencias en la forma del ala entre jóvenes y adultos: media del mínimo cuadrado $( \pm S E)$ de la longitud de las plumas primarias para adultos (negro) y juveniles (gris), controlando el tamaño del cuerpo (longitud del antebrazo o NF). En los paseriformes no se ha tenido en cuenta la pluma vestigial (P10).] 

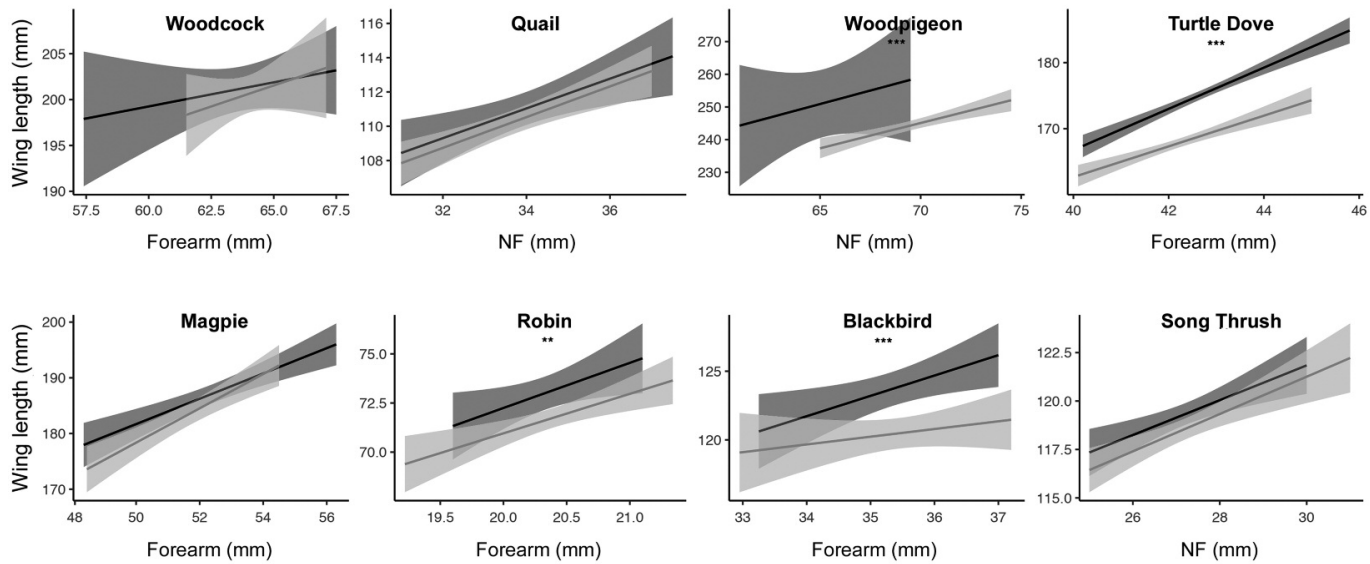

FIG. 4.-Graphical representation $( \pm \mathrm{SD})$ of the differences in wing length between juveniles (grey) and adults (black), controlling for body size measure (forearm or non-feathered part of wing (NF)). ${ }^{*} \mathrm{P}<0.05 ;{ }^{* *} \mathrm{P}<0.01 ;{ }^{* * *} \mathrm{P}<0.001$.

[Representación gráfica $( \pm S D)$ de las diferencias en la longitud del ala entre juveniles (gris) y adultos (negro), controlando por el tamaño corporal (antebrazo o NF). ${ }^{*} P<0,05$; ${ }^{* *} P<0,01$; ${ }^{* * *} P<0,001$.]

studied non-passerines. However, in rounded wings such as those of passerines, where the wing tip is displaced towards the central primaries (P7, P6 or P5 in our study species), the interpretation of variation in $\mathrm{C} 2$ scores is less intuitive. In this case, P9 (the outermost feather) of adult passerines grows less than P7, P6 and P5, which determine the wing tip in these species. Therefore, the greater growth in the wing tip feathers, along with less growth in more distal feathers, causes the wing tip to protrude more, giving adult passerines more pointed wings than juveniles and making $\mathrm{C} 2$ values more difficult to interpret than in nonpasserine species. Hence, the interpretation of $\mathrm{C} 2$ values depends on the wing shape of the species, which should be taken into account in comparative studies of wing shape in birds based on SCCA. The C2 axis is a linear vector whose values and interpretation are subject to the correlations between the variables that generate it. Hence, if the ontogeny and the allometry of feathers vary between species, C2 will mean different things in each species, making it more diffi- cult to analyse general patterns based solely on changes in $\mathrm{C} 2$. Thus, we subsequently disregarded $\mathrm{C} 2$ values in the interpretation of wing shape in species that do not have the wing tip in the distal feathers. Instead, we interpret wing shape from the graphical approximation, the growth of each primary feather and the shape change that this growth entails.

Looking at the graphical approximation of wings, in the studied non-passerines the effect of the first complete moult was the development of a more rounded wing, while Robins, Blackbirds and Magpies developed more pointed wings during the first complete moult. Song Thrushes did not significantly change wing shape with the first moult. Interestingly, Woodcock juveniles, unlike Western Sandpipers but similarly to the other non-passerines, had more pointed wings than adults, indicating that birds of the same order (Charadriiformes) and family (Scolopacidae) may show opposite patterns of wing shape change among ages (Fernández \& Lank, 2007). Unfortunately, Fernández \& 
Lank (2007) did not provide detailed SCCA results and therefore we cannot check their interpretation of the $\mathrm{C} 2$ axis.

In any case, our results show that four non-passerine species from three different and phylogenetically distant orders (Prum et $a l ., 2015)$ have the same strategy, developing a more rounded wing during their first complete moult. These species are all migrants, but they also have pronounced terrestrial habits (del Hoyo et al., 1994; del Hoyo et al., 1996; del Hoyo et al., 1997). It is possible that their juveniles are relatively more affected by the selection force of migration, where more pointed wings improve their chances of surviving the first migration (Bowlin \& Wikelski, 2008; Vágási et al., 2016), an interpretation that was put forward in an earlier study on the Turtle Dove (Cabodevilla et al., 2018). However, a more pointed wing in juveniles has also been found in Red-legged Partridges (Nadal et al., 2017), which are not migratory. Taken together, these results indicate that ontogenetic variation in wing shape may exist in migratory and non-migratory birds alike, and trends towards adults or juveniles showing more pointed wings may evolve in different bird lineages. This variability suggests that diverse selection forces are shaping the wings of different avian groups, for which flight requirements at each age may be contingent on species-specific features (flight mode, body size, migration pattern, etc.). Further research is needed to determine which species features best explain variation in the ontogeny of wing shape among birds.

Our results emphasise that the pattern of variation in wing shape between age groups is different between passerines and the studied non-passerines, due to a variable pattern of elongation in different primary feathers during the moult. Our data indicate, as has been shown previously (Cabodevilla et al., 2018), in general, with the first complete moult new primary feathers grow longer, particularly in non-passerines. However, at the same time, each feather grows in different proportions. In addition, the growth of each primary feather was proportionally different between groups. As has already been reported for the Turtle Dove (Cabodevilla et $a l ., 2018)$, in the studied non-passerines the central primaries show the greatest increase in length, resulting in the more rounded adult wing. On the other hand, smaller differences in length increase among central and proximal primary feathers were found in passerines, and the largest differences were in the most distal feather, which was shorter in adults than in juveniles. Taking into account that the wing tip of these species is closer to the central primaries, this difference in feather elongation leads to a more pointed wing after the first complete moult in passerines. Previous works have disregarded the contribution of the 10th primary feather (vestigial primary feather) to wing shape (Milá et al., 2008; Green et al., 2009; de la Hera et al., 2014), but our results clearly show the importance of this feather, suggesting that it may affect flight performance in juvenile passerine birds. For the same reason, it would be interesting to analyse the length of the outermost primary feather in future studies of nonpasserines with more than ten primaries.

In contrast to expectations (Alatalo et al., 1984; Figuerola \& Gutiérrez, 2000; Green et al., 2009; McKinnon et al., 2014), the length increase in almost all primary feathers during the first complete moult did not result in longer wing lengths in adults in half of the study species. Feathers increase their length differently in different species, and the feather that defines the wing tip did not always grow significantly longer during the first moult. This was the case in Woodcock, Quail, Magpie and Song Thrush, which have a wing tip on P10, P9, P5 and P7, respectively. These feathers did not vary significantly in length among age groups in the corresponding species. 
In this study, we did not take into account the sex or origin of the individuals, two parameters that are strongly related to wing morphology (Lockwood et al., 1998; Fernández \& Lank, 2007; Nadal et al., 2017), since we lacked this information for measured birds. In any case, as observed in previous works (Fernández \& Lank, 2007; Nadal et al., 2017), the non-inclusion of the sex variable does not seem to be problematic, but its inclusion would increase the explained variance of the data. On the other hand, data collected during migration periods is not expected to have an origin bias between age groups (Cabodevilla et al., 2018). For example, juveniles should not have more pointed wings because they come from further away than the adults captured at the same time. However, we cannot be certain of this and it must be considered in future studies.

To summarise, our results show that agerelated variation in wing shape does not occur in the same way in all bird species or bird orders, and the first complete moult does not always lead to increased wing length in adults. In addition, our results have also elucidated a potential pitfall in the use of one of the most common indexes to describe wing shape (SCCA), particularly in birds with rounded wings as in many passerine species.

Data Availability Statement.-The data that support the findings of this study are available from the corresponding author upon reasonable request.

AcKnowledgements. - We would like to thank Miguel Juan Martínez, José Luis Martínez, Esther Descalzo, Jesús Joaquín Cabodevilla, Marta Herrero, Elena Fernandez, Edu Laguna and all colleagues who helped to collect the samples in the field. We also thank all hunters who collaborated with us, providing wings of hunted birds, two anonymous referees for constructive comments on the manuscript and Sarah Young, who helped to revise the English text. Xabier Cabodevilla was supported by a PhD Grant, financed by the Basque Country Government (Grant no. PRE_2018_2_0273).

Author CONTRIBUTIONS.-B.A. and X.C. formulated the research question. X.C. performed the formal analyses and wrote the initial draft of the manuscript. B.A. performed the SCCA analysis in SAS and supervised the work. J.P.-T., L.M.-Z., A.P.-R., J.F.L.-B, M.C.C., D.V., R.I. and A.G. performed the field work and contributed to discussions. X.C., B.A., J.P.-T., L.M.-Z. and A.P.-R contributed to the text of the final version.

\section{REFERENCES}

Alatalo, R.V., Gustafsson, L. \& Lundbkrg, A. (1984). Why do young passerine birds have shorter wings than older birds? Ibis, 126: 410415.

Arizaga, J. \& Barba, E. (2011). Differential timing of passage of populations of migratory Blackcaps (Sylvia atricapilla) in Spain: evidence from flight-associated morphology and recoveries. Ornis Fenn., 88: 104-109.

Biewener, A. \& Patek, S. (2018). Animal locomotion. Oxford University Press.

Bowlin, M.S. \& Wikelski, M. (2008). Pointed wings, low wingloading and calm air reduce migratory flight costs in songbirds. PLOS ONE, 3: e2154.

Burns, J.G. \& Ydenberg, R.C. (2002). The effects of wing loading and gender on the escape flights of least sandpipers (Calidris minutilla) and western sandpipers (Calidris mauri). Behav. Ecol. Sociobiol., 52: 128-136.

Cabodevilla, X., Moreno-Zarate, L. \& Arroyo, B. (2018). Differences in Wing morphology between juvenile and adult European Turtle Doves Streptopelia turtur: implications for migration and predator escape. Ibis, 160: 458-463. de la Hera, I., Pulido, F. \& Visser, M.E. (2014). Longitudinal data reveal ontogenetic changes in the wing morphology of a long-distance migratory bird. Ibis, 156: 209-214. 
del Hoyo, J., Elliot, A. \& Sargatal, J. (1994). Handbook of the Birds of the World, Vol. 2. Lynx Edicions. Barcelona.

del Hoyo, J., Elliot, A. \& Sargatal, J. (1996). Handbook of the Birds of the World, Vol. 3. Lynx Edicions. Barcelona.

del Hoyo, J., Elliot, A. \& Sargatal, J. (1997). Handbook of the Birds of the World, Vol. 4. Lynx Edicions. Barcelona.

Demongin, L. (2013). Guide d'identification des oiseaux en main. Les 250 espèces les plus baguées en France. Beauregard-Vendon.

Fernández, G. \& Lank, D.B. (2007). Variation in the wing morphology of Western Sandpipers (Calidris mauri) in relation to sex, age class, and annual cycle. Auk, 124: 1037-1046.

Figuerola, J. \& Gutiérrez, R. (2000). Why do juvenile Moustached Warblers have shorter wings? Ornis Fenn., 77: 183-187.

Furness, E.N. \& Furness, R.W. (2016). Influences of feather wear and age on wing lengths of Blue Tits Cyanistes caeruleus. Ringing Migr., 31: 1-5.

Gill, F. \& Donsker, D. (2019). IOC World Bird List (v9.1). doi:10.14344/IOC.ML.9.1.

Green, D.J., Whitehorne, I.B., Taylor, A.L. \& Drake, E.L. (2009). Wing morphology varies with age but not migratory habit in American Dippers. Wilson J. Ornithol., 121: 141-147.
Hickman, C.P., Roberts, L.S., Keen, S.L., Larson, A., I'Anson, H., Eisenhour, D.J., Ober, W.C. \& Garrison, C.W. (2008). Integrated principles of zoology (14ed). McGraw-Hill. New York. Huber, G.H., Turbek, S.P., Bostwick, K.S. \& Safran, R.J. (2016). Comparative analysis reveals migratory swallows (Hirundinidae) have less pointed wings than residents. Biol. J. Linn. Soc., 120: 228-235.

Indykiewicz, P., Minias, P., Kowalski, J., \& Podlaszczuk, P. (2019). Shortcomings of discriminant functions: A case study of sex identification in the Black-headed Gull. Ardeola, 66: 361-372.

Lockwood, R., Swaddle, J.P. \& Rayner, J.M. (1998). Avian wingtip shape reconsidered: wingtip shape indices and morphological adaptations to migration. J. Avian Biol., 29: 273292.

McFarlane, L., Altringham, J.D. \& Askew, G.N. (2016). Intra-specific variation in wing morphology and its impact on take-off performance in blue tits (Cyanistes caeruleus) during escape flights. J. Exp. Biol., 219: 1369-1377.

McKinnon, E.A., Fraser, K.C., Stanley, C.Q. \& Stutchbury, B.J. (2014). Tracking from the tropics reveals behaviour of juvenile songbirds on their first spring migration. PLOS ONE, 9: e105605.

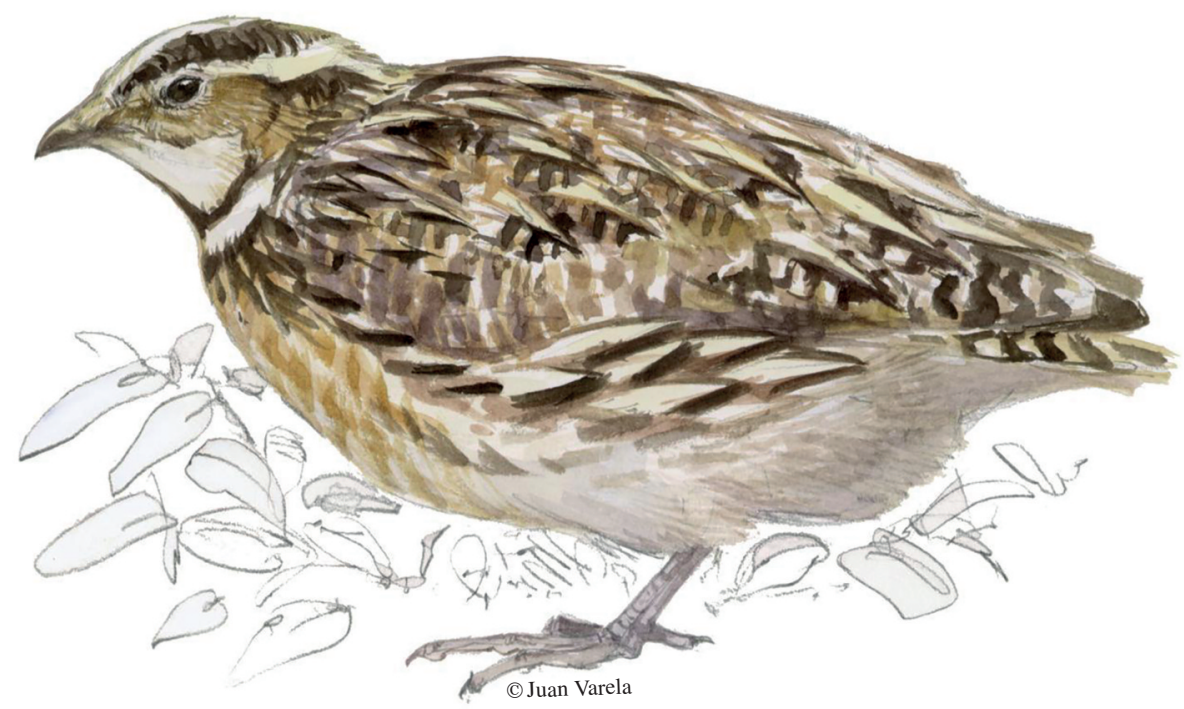

Ardeola 67(2), 2020, 341-354 
Milá, B., Wayne, R.K. \& Smith, T.B. (2008). Ecomorphology of migratory and sedentary populations of the yellow-rumped warbler (Dendroica coronata). Condor, 110: 335-344.

Minias, P., Meissner, W., Włodarczyk, R., Ożarowska, A., Piasecka, A., Kaczmarek, K. \& Janiszewski, T. (2015). Wing shape and migration in shorebirds: a comparative study. Ibis, 157: 528-535.

Nadal, J., Ponz, C. \& Margalida, A. (2017). Feathers for escape: the transition from juvenile to adult in red-legged partridges (Alectoris rufa). Biol. J. Linn. Soc., 123, 72-80.

Norberg, U.M. (1995). Wing design and migratory flight. Isr. J. Zool., 41: 297-305.

Nowakowski, J. (2002). Variation of morphometric parameters within the Savi's Warbler ( $\mathrm{Lo}$ custella luscinioides) population in eastern Poland. Ring, 24: 49-67.

Pérez-Tris, J. \& Tellería, J.L. (2001). Age-related variation in wing shape of migratory and sedentary Blackcaps Sylvia atricapilla. J. Avian Biol., 32: 207-213.

Prum, R.O., Berv, J.S., Dornburg, A., Field, D.J., Townsend, J.P., Lemmon, E.M. \& Lemmon, A.R. (2015). A comprehensive phylogeny of birds (Aves) using targeted next-generation DNA sequencing. Nature, 526: 569-577.

R Core Team (2019). R: A language and environment for statistical computing. Vienna, Austria: R Foundation for Statistical Computing. URL https://www.Rproject.org/.

Russell, V.L. (2016). Least-squares means: the R Package lsmeans. J. Stat. Softw., 69: 1-33.

SAS Institute, Inc. (2002). SAS Online Doc: Version 9.1. Cary, NC, USA.

Savile, D.B.O. (1957). Adaptive evolution in the avian wing. Evolution, 11: 212-224.

Senar, J.C., Lleonart, J. \& Metcalfe, N.B. (1994). Wing-shape variation between resident and transient wintering Siskins Carduelis spinus. J. Avian Biol., 25: 50-54.

Snow, D.W., Perrins, C.M., Hillcoat, B., Gillmor, R. \& Roselaar, C.S. (1997). The birds of the Western Palearctic. Oxford University Press. Svensson, L. (1992). Identification guide to European passerines. British Trust for Ornithology.
Swaddle, J.P. \& Lockwood, R. (1998). Morphological adaptations to predation risk in passerines. J. Avian Biol., 29: 172-176.

Swaddle, J.P. \& Lockwood, R. (2003). Wingtip shape and flight performance in the European Starling Sturnus vulgaris. Ibis, 145: 457-464. Vágási, C.I., Pap, P.L., Vincze, O., Osváth, G., Erritzøe, J. \& Møller, A.P. (2016). Morphological Adaptations to Migration in Birds. Evol. Biol., 43: 48-59.

Venables, W.N. \& Ripley, B.D. (2002). Modern Applied Statistics with S. Fourth Edition. Springer, New York.

Watanabe, Y.Y. (2016). Flight mode affects allometry of migration range in birds. Ecol. Lett., 19: 907-914.

Wickham, H. (2016). ggplot2: Elegant Graphics for Data Analysis. Springer-Verlag New York.

Winkler, H. \& Leisler, B. (1992). On the ecomorphology of migrants. Ibis, 134: 21-28.

\section{SuPPLEMENTARY ELECTRONIC MATERIAL}

Additional supporting information may be found in the online version of this paper. See the volume 67(2) on www.ardeola.org

\section{APPENDIX 1.}

Figure A1. Locations of sampling regions for species.

Figure A2. Simulation of wing morphology change during the first complete moult.

\section{APPENDIX 2. Model summaries.}

Table B1. Summary of SCCA analyses.

Table B2. GLM of primary feather length of each species.

Table B3. Tukey post-hoc analysis for the GLMs testing for primary length differences between age groups.

Submitted: September 28, 2019 Major revisión: December 27, 2019 Second version arrived: January 15, 2020 Accepted: February 23, 2020

Editor: J.A. Masero 